ZOOLOGIA 27 (6): 887-891, December, 2010

doi: $10.1590 /$ S1984-46702010000600008

\title{
Reproductive biology of Palmistichus elaeisis (Hymenoptera: Eulophidae) with alternative and natural hosts
}

\author{
Fabricio F. Pereira", 4; José C. Zanuncio²; Patrik L. Pastori"; Roberto A. Chichera ${ }^{1}$; \\ Gilberto S. Andrade² \& José E. Serrão ${ }^{3}$
}

\author{
${ }^{1}$ Faculdade de Ciências Biológicas e Ambientais, Universidade Federal da Grande Dourados. Rodovia Dourados-Itahum, \\ km 12, Caixa Postal 241, 79804-970 Dourados, MS, Brazil. \\ 2 Departamento de Biologia Animal, Universidade Federal de Viçosa. 36570-000 Viçosa, MG, Brazil. \\ ${ }^{3}$ Departamento de Biologia Geral, Universidade Federal de Viçosa. 36570-000 Viçosa, MG, Brazil. \\ ${ }^{4}$ Corresponding author. E-mail: fabriciofagundes@ufgd.edu.br
}

\begin{abstract}
Mass rearing of parasitoids depends on choosing appropriate alternative hosts. The objective of this study was to select alternative hosts to rear the parasitoid Palmistichus elaeisis Delvare \& LaSalle, 1993 (Hymenoptera: Eulophidae). Pupae of the lepidopterans Anticarsia gemmatalis Hübner, 1818 (Lepidoptera: Noctuidae), Bombyx mori Linnaeus, 1758 (Lepidoptera: Bombycidae) and Thyrinteina arnobia (Stoll, 1782) (Lepidoptera: Geometridae) were exposed to parasitism by females of $P$. elaeisis. The duration of the life cycle of $P$. elaeisis was $21.60 \pm 0.16$ and $24.15 \pm 0.65$ days on pupae of $A$. gemmatalis and B. mori, respectively, with $100.0 \%$ parasitism of the pupae and 71.4 and $100.0 \%$ emergence of parasitoids from the first and second hosts, respectively. The offspring number of $P$. elaeisis was $511.00 \pm 49.70$ and $110.20 \pm 19.37$ individuals per pupa of $B$. mori and A. gemmatalis, respectively. The reproduction of $P$. elaeisis from pupae of $T$. arnobia after six generations was similar to the other hosts.
\end{abstract}

KEY WORDS. Anticarsia gemmatalis; Bombyx mori; parasitoids; Thyrinteina arnobia.

Parasitoids are important for biological control of insect pests in agro-ecosystems due to their diversity and to the high levels of population regulation of insects in different orders (Pennacchio \& Strand 2006). Most of these natural enemies belong to several families of Hymenoptera, including Eulophidae, which are comprised of 297 genera and 4,472 species, thus far described in tropical and temperate areas exhibiting a wide range of biological traits. For example, some species are endo or ectoparasitoids, idiobionts or koinobionts. They may be solitary or gregarious, primary or hyperparasitoids, specialists or generalists and many of these species have been studied and used with success in biological control programs (GAUTHIER et al. 2000).

Palmistichus elaeisis Delvare \& LaSalle, 1993 (Hymenoptera: Eulophidae) is a polyphagous parasitoid with reports of parasitism on pupae of several lepidopteran hosts, including Eupseudosoma involuta (Sepp, 1852) (Lepidoptera: Arctiidae), Euselasia eucerus Hewitson, 1872 (Lepidoptera: Riodinidae), Sabulodes sp., Thyrinteina arnobia (Stoll, 1782), and T. leucoceraea Rindge, 1961 (Lepidoptera: Geometridae) (Delvare \& LaSalle 1993, Bittencourt \& Berti Filho 1999, Pereira et al. 2008b), which occur in eucalyptus plantations of Brazil. The generalist habit of $P$. elaeisis demonstrates that this natural enemy can be used to control Lepidoptera eucalyptus defoliators, primarily species of the genus Thyrinteina (Pereira et al. 2008b). However, rational evaluations, supported by ecological data, are necessary to prevent possible unpredictable negative impact of this natural enemy after its release, due to its generalist habit (WAAGE 2001).

The success of biological control with parasitoids species depends on basic studies of hosts and other environmental features which could affect their development (Pratissoli et al. 2005, Pastori et al. 2007, Pereira et al. 2009, 2010). Moreover, these natural enemies, reared on alternative hosts with lower production costs and without reduction on their efficiency when compared with their natural hosts, may have economic benefits (Pratissoli et al. 2005, Zanuncio et al. 2008).

The silkworm, Bombyx mori Linnaeus, 1758 (Lepidoptera: Bombycidae) can be reared with low cost and the pupae contain high levels of protein (GreIss et al. 2003, WANG-Duu et al. 2004). Anticarsia gemmatalis Hübner, 1818 (Lepidoptera: Noctuidae) has a short life cycle and can also be maintained on artificial diet in the laboratory (GreEne et al. 1976). The parasitoid P. elaeisis also has been reared on pupae of $B$. mori in the laboratory (Bittencourt \& Berti Filho 1999, 2004). Therefore, $B$. mori and $A$. gemmatalis are potential alternative hosts for $P$. elaeisis and, for this reason the objective of this study was to select the most appropriate host for rearing the parasitoid and to evaluate its reproductive success from these alternative hosts, as opposed to the natural host T. arnobia. 


\section{MATERIAL AND METHODS}

Considering rearing the lepidopteran hosts of the parasitoid P. elaeisis: 1) Dirphia moderata Bouvier, 1929 (Lepidoptera: Saturniidae) was reared using a methodology adapted from Pereira et al. (2008a). The parasitoid P. elaeisis was reared for one generation with the host $D$. moderata to avoid its conditioning before rearing it on B. mori and A. gemmatalis pupae. 2) Bombyx mori caterpillars were reared in plastic trays $(39.3 \mathrm{x}$ 59.5 x $7.0 \mathrm{~cm}$ ) with Morus alba Linnaeus, 1753 (Rosales: Moraceae) leaves supplied daily. The cocoons were transferred to plastic trays $(28.3 \times 36.0 \times 7.0 \mathrm{~cm})$ at $25 \pm 2{ }^{\circ} \mathrm{C}, 70 \pm 10 \%$ relative humidity and photophase of 14 h. 3) Eggs of $A$. gemmatalis were maintained on moistened paper filter inside Petri dishes $(10.0 \times 2.5 \mathrm{~cm})$. Newly-emerged caterpillars were transferred to plastic containers where they were provided with artificial diet (GreENe et al. 1976) at $25 \pm 1^{\circ} \mathrm{C}, 70 \pm 10 \%$ relative humidity and photophase of $14 \mathrm{~h}$ until pupation. 4) Thyrinteina arnobia caterpillars were placed in glass tubes $(8.5 \times 2.4 \mathrm{~cm})$, covered with cotton and provided with artificial diet (WILCKEN $\&$ BERTI FILHO 2006).

Adults of the parasitoid P. elaeisis were reared in glass tubes $(14.0 \times 2.2 \mathrm{~cm})$ closed with a cotton wad and with honey droplets as food. Forty-eight to $72 \mathrm{~h}$ old pupae of $B$. mori were removed from the cocoons and exposed to parasitism by $P$. elaeisis females over the course of $24 \mathrm{~h}$ at $25 \pm 2^{\circ} \mathrm{C}, 70 \pm 10 \%$ relative humidity and a photophase of $14 \mathrm{~h}$. Forty-eight hour old pupae of $D$. moderata were exposed to $P$. elaeisis during 24 h. After emergence, adults of this parasitoid were divided into two groups and reared for three generations on alternative hosts A. gemmatalis or B. mori to remove preimaginal conditioning of parasitoids. Fifteen $A$. gemmatalis pupae $(0.24 \pm 0.004 \mathrm{~g})$ and $1524 \mathrm{~h}$ old $B$. mori pupae $(1.2 \pm 0.05 \mathrm{~g})$ were placed individually in glass tubes $(14.0 \times 2.2 \mathrm{~cm})$ and exposed to parasitism by six and 45 P. elaeisis females (Pereira et al. 2010), respectively, during $24 \mathrm{~h}$ at $25 \pm 1^{\circ} \mathrm{C}, 70 \pm 10 \%$ relative humidity and photophase of $14 \mathrm{~h}$. The ideal number of $P$. elaeisis for the different hosts was previously estimated based on the minimum number needed to overcome the host immunity (see Pereira et al. 2010). All P. elaeisis were removed from the tubes at the end of this period.

The reproductive performance of $P$. elaeisis on natural host T. arnobia was determined with adults reared for six generations on A. gemmatalis or B. mori pupae. Twenty-eight $48 \mathrm{~h}$ old pupae of $T$. arnobia were sexed, weighed ( 7 female $=0.60 \pm 0.04 \mathrm{~g}$ and 7 male $=0.13 \pm 0.01 \mathrm{~g} ; 7$ female $=0.69 \pm 0.07 \mathrm{~g}$ and 7 male $=$ $0.24 \pm 0.02 \mathrm{~g}$ ), and separately placed in glass tubes where they were exposed over $72 \mathrm{~h}$ to parasitism by P. elaeisis females reared for six generations on A. gemmatalis or B. mori pupae. Based on preliminary tests, we used six females of $P$. elaeisis per male pupa of T. arnobia, and 15 females per female pupa.

The duration of the life cycle (egg-adult); percent parasitism - discounting natural mortality of the host (Аввотт
1925) -; percent emerging; number of parasitoid individuals emerged per pupa of each host; longevity of descendants and sex ratio were evaluated.

The experimental design was completely randomized using two treatments where $P$. elaeisis was reared with each alternative host (A. gemmatalis or B. mori) with 15 replications each with one host pupa. The same design was used, but each treatment had 14 replications represented by the biological aspects of $P$. elaeisis obtained from pupae of T. arnobia but on which they had been previously reared on $A$. gemmatalis or $B$. mori. The treatments were submitted to analysis of variance (ANOVA) followed by the F test using the software SAEG 8.0. Percent parasitism and emergence of $P$. elaeisis were analyzed with general linear models (GLM) of binomial distributions ( $p$ $\leqslant 0.05$ ) using the R Statistical System (IhaKa \& Gentleman 1996).

\section{RESULTS}

The life cycle (egg to adult) of P. elaeisis was shorter when reared on A. gemmatalis than on B. mori $(\mathrm{F}=11.369, \mathrm{p}=0.003)$. Palmistichus elaeisis parasitism reached $100 \%$ on B. mori and on A. gemmatalis pupae. The emergence of progeny was $100 \%$ on parasitized pupae of B. mori and $71.4 \%$ on A. gemmatalis $\left(\chi^{2}=5.900, \mathrm{p}=0.015\right)$ (Tab. I). More P. elaeisis emerged from $B$. mori pupae than from $A$. gemmatalis pupae $(\mathrm{F}=45.502$, $\mathrm{p}=0.0001$ ). However, a larger number of females was produced per female of $P$. elaeisis from A. gemmatalis pupae ( $\mathrm{F}=5.563$, $\mathrm{p}=0.028)$ (Tab. I).

The length of the body (head to the abdominal extremity) $(\mathrm{F}=15.445, \mathrm{p}=0.0005)$ and the width of the head capsule $(\mathrm{F}=35.196, \mathrm{p}=0.0001)$ of $P$. elaeisis females emerging from $B$. mori pupae increased when compared to those of A.gemmatalis. However, the length of the body $(\mathrm{F}=2.135, \mathrm{p}=0.155)$ and the width of the head capsule $(\mathrm{F}=3.903, \mathrm{p}=0.06)$ of males were similar on both hosts (Tab. I).

The longevity of $P$. elaeisis females and males emerging from B. mori and A. gemmatalis was similar $(\mathrm{F}=2.147, \mathrm{p}=0.147)$ for females $(F=0.89, p=0.0001)$ for males (Tab. I). The sex ratio was similar for offspring originating from $A$. gemmatalis and B. mori (Tab. I).

There were no differences in parasitism $\left(\chi^{2}=2.9392\right.$, $\mathrm{p}=0.086)$, emergence of offspring $\left(\chi^{2}=1.3426, \mathrm{p}=0.247\right)$, life cycle length (egg to adult) $(\mathrm{F}=2.402, \mathrm{p}=0.137)$, progeny per pupa $(\mathrm{F}=1.842, \mathrm{p}=0.190)$, female $(\mathrm{F}=2.267, \mathrm{p}=0.144)$ and male $(\mathrm{F}=1.499, \mathrm{p}=0.232)$ body length, female $(\mathrm{F}=3.099$, $\mathrm{p}=0.090)$ and male $(\mathrm{F}=2.278, \mathrm{p}=0.143)$ head capsule width, female $(\mathrm{F}=0.037, \mathrm{p}>0.05)$ and male $(\mathrm{F}=0.007, \mathrm{p}>0.05)$ longevity and sex ratio $(\mathrm{F}=2.442, \mathrm{p}=0.134)$ in $T$. arnobia parasitized by $P$. elaeisis after being previously reared on $A$. gemmatalis or B. mori (Tab. II). On the other hand, the number of offspring per female was higher in T. arnobia pupae ( $\mathrm{F}=5.009$, $\mathrm{p}=0.037$ ) after the parasitoid was reared with A. gemmatalis pupae (Tab. II). 
Table I. Reproductive characteristics (mean \pm standard error) of $P$. elaeisis when reared on pupae of $B$. mori or A. gemmatalis.

\begin{tabular}{|c|c|c|c|c|}
\hline Reproductive characteristics & Bombyx mori (Means $\pm \mathrm{SE})^{1}$ & $(n)$ & Anticarsia gemmatalis (Means \pm SE) ${ }^{1}$ & (n) \\
\hline Life cycle duration (days) & $24.15 \pm 0.65$ & 13 & $21.60 \pm 0.16$ & 10 \\
\hline Progeny per pupa & $511.00 \pm 49.70$ & 13 & $110.20 \pm 19.37$ & 10 \\
\hline Females produced per female & $10.64 \pm 1.02$ & 13 & $17.68 \pm 3.15$ & 10 \\
\hline Female body length (mm) & $1.85 \pm 0.03$ & 15 & $1.65 \pm 0.04$ & 15 \\
\hline Male body length (mm) & $1.38 \pm 0.03$ & 10 & $1.32 \pm 0.03$ & 10 \\
\hline Female head capsule width (mm) & $0.52 \pm 0.01$ & 15 & $0.46 \pm 0.01$ & 15 \\
\hline Male head capsule width (mm) & $0.41 \pm 0.01$ & 10 & $0.39 \pm 0.01$ & 10 \\
\hline Female longevity (days) & $17.55 \pm 1.84$ & 40 & $14.63 \pm 0.78$ & 40 \\
\hline Male longevity (days) & $16.40 \pm 2.26$ & 10 & $13.70 \pm 1.50$ & 10 \\
\hline Sex ratio (female/total) & $0.94 \pm 0.01$ & 13 & $0.96 \pm 0.01$ & 10 \\
\hline
\end{tabular}

${ }^{1}$ Values which differ between hosts (F-test at $5 \%$ probability) are shown in bold.

Table II. Reproductive characteristics (mean \pm standard error) of $P$. elaeisis when reared on pupae of $T$. arnobia after six generations on pupae of B. mori or A. gemmatalis.

\begin{tabular}{|c|c|c|c|c|}
\hline Reproductive characteristics & Bombyx mori (Means $\pm \mathrm{SE})^{1}$ & $\mathrm{n}$ & Anticarsia gemmatalis (Means $\pm \mathrm{SE})^{1}$ & $\mathrm{n}$ \\
\hline Life cycle duration (days) & $20.64 \pm 0.28$ & 11 & $21.00 \pm 0.30$ & 11 \\
\hline Progeny per pupa & $319.45 \pm 74.87$ & 13 & $493.27 \pm 1.04$ & 10 \\
\hline Females produced per female & $24.64 \pm 3.50$ & 11 & $39.31 \pm 4.67$ & 11 \\
\hline Female body length (mm) & $1.95 \pm 0.03$ & 15 & $1.88 \pm 0.03$ & 15 \\
\hline Male body length (mm) & $1.38 \pm 0.02$ & 15 & $1.34 \pm 0.02$ & 15 \\
\hline Female head capsule width ( $\mathrm{mm}$ ) & $0.59 \pm 0.02$ & 15 & $0.55 \pm 0.01$ & 15 \\
\hline Male head capsule width (mm) & $0.42 \pm 0.00$ & 15 & $0.41 \pm 0.00$ & 15 \\
\hline Female longevity (days) & $23.75 \pm 2.12$ & 40 & $23.15 \pm 2.32$ & 40 \\
\hline Male longevity (days) & $24.80 \pm 4.10$ & 10 & $24.30 \pm 4.17$ & 10 \\
\hline Sex ratio (female/total) & $0.95 \pm 0.01$ & 11 & $0.93 \pm 0.01$ & 11 \\
\hline
\end{tabular}

${ }^{1}$ Values which differ between hosts (F-test at $5 \%$ probability) are shown in bold.

\section{DISCUSSION}

The offspring of P. elaeisis showed a shorter development time on A. gemmatalis pupae, which may be due to differences of nutritional resources between hosts. Thus, A. gemmatalis may have a reduced availability of nutritional resources which stimulates the parasitoids to develop faster, but with a smaller size. On the other hand, parasitoids can adjust the number of its population according to the size of the natural host, thus avoiding sibling competition for a limited resource (Zaviezo \& Mills 2000). Furthermore, the parasitoids had increased emergence from B. mori than from A. gemmatalis, indicating that host quality can vary with the host (VINSON \& IWANTSCH 1980, JeRvis et al. 2008). These results demonstrate that the host species affect the development period of this parasitoid (BITTENCOURT \& Berti Filho 2004).
The size of $P$. elaeisis adults from B. mori and A. gemmatalis pupae were adequate for quality control in their production and use due to similarities in the biological parameters of $P$. elaesisis from T. arnobia. This is important, because the body size in many parasitoids is positively correlated with important functional traits including mating, fecundity, reproductive longevity, emergence of progeny and sex ratio (SAGARRA et al. 2001, Moreira et al. 2009).

The similar longevity of $P$. elaeisis females and males when reared on B. mori and A. gemmatalis pupae shows that this parasitoid was not affected by these hosts. This has also been reported for Hyssopus pallidus (Askew, 1964) (Hymenoptera: Eulophidae) on Cydia molesta (Busck, 1916) and Cydia pomonella (Linnaeus, 1758) (Lepidoptera: Tortricidae) pupae (HäCKERMANN et al. 2007). However, it differs from results for M. acasta when developing on C. erythrocephala pupae of different ages (IMANDEH 
2006). This indicates that some parasitoids are not able to convert energy gained to increase their longevity (HeIn \& DorN 2008).

The offspring sex ratio of $P$. elaeisis was similar when developing on B. mori and A. gemmatalis pupae. This was also reported for this parasitoid on Diatraea saccharalis (Fabricius, 1794) (Lepidoptera: Crambidae) (Bittencourt \& Berti Filho 1999) and previously refrigerated $B$. mori pupae (PEREIRA et al. 2009). This was also similar to Melittobia clavicornis (Cameron, 1908) (Hymenoptera: Eulophidae) developing on Trypoxylon politum Say, 1837 (Hymenoptera: Sphecidae), Neobellieria bullata (Parker, 1916) (Diptera: Sarcophagidae) and Antrax sp. (Diptera: Bombyliidae) pupae (GonzÁles et al. 2004). However, the sex ratio of Hymenoptera can vary with the stage, age or nutritional status of the host as well as the age of the parasitoid (UçKAN \& GÜLel 2002), besides the temperature (Pereira et al. 2004, Pratissoli et al. 2006, Pandey \& Tripathi 2008, Pastori et al. 2008).

The reproductive success, the capacity to produce females, and the complete development characteristics of B. mori and A. gemmatalis pupae indicate that they are appropriate hosts for P. elaeisis. Moreover, the development and reproduction of P. elaeisis on pupae of the natural host T. arnobia were not reduced after six generations on A. gemmatalis and B. mori pupae, which demonstrates that this parasitoid can be easily reared with A. gemmatalis and B. mori for the biological control of $T$. arnobia.

\section{ACKNOWLEDGEMENTS}

Thanks to the Conselho Nacional de Desenvolvimento Científico e Tecnológico (CNPq), the Coordenação de Aperfeiçoamento de Pessoal de Nível Superior (CAPES) and to the Fundação de Amparo à Pesquisa do Estado de Minas Gerais (FAPEMIG) for financial support.

\section{LITERATURE CITED}

Аввотт, W.S. 1925. A method of computing the effectiveness of an insecticide. Journal of Economic Entomology 18: 265267.

Bittencourt, M.A.L. \& E. Berti Filho. 1999. Preferência de Palmistichus elaeisis por pupas de diferentes lepidópteros pragas. Scientia Agricola 56: 1281-1283.

Bittencourt, M.A.L. \& E. Berti Filho. 2004. Desenvolvimento dos estágios imaturos de Palmistichus elaeisis Delvare \& LaSalle (Hymenoptera, Eulophidae) em pupas de Lepidoptera. Revista Brasileira de Entomologia 48: 65-68.

Delvare, G. \& J. LaSalle. 1993. A new genus of Tetrastichinae (Hymenoptera: Eulophidae) from the Neotropical region, with the description of a new species parasitic on key pests of oil palm. Journal of Natural History 27: 435-444.

Gauthier, N.; J. LaSalle; D.L.J. Quicke \& H.C.J. Godfray. 2000. Phylogeny of Eulophidae (Hymenoptera: Chalcidoidea), with a reclassification of Eulophinae and the recognition that
Elasmidae are derived eulophids. Systematic Entomology 25: 521-539.

Gonzáles, J.M.; J. Abe \& R.W. Matthews. 2004. Offspring production and development in the parasitoid wasp Melittobia clavicornis (Cameron) (Hymenoptera: Eulophidae) from Japan. Entomological Science 7: 15-19.

Greiss, H.; N. Petrov; K. Boitchev \& Z. Petkov. 2003. Study on improved technology for silkworm Bombyx mori L. rearing in Egypt. II. Commercial egg production. Bulgarian Journal of Agriculture Science 9: 109-112.

Greene, G.L.; N.C. Leppla \& W.A. Dickerson. 1976. Velvetbean caterpillar: a rearing procedure and artificial medium. Journal of Economic Entomology 69: 487-488.

Häckermann, J.; A.S. RotT \& S. Dorn. 2007. How two different host species influence the performance of a gregarious parasitoid: Host size is not equal to host quality. Journal of Animal Ecology 76: 376-383.

Hein, S. \& S. Dorn. 2008. The parasitoid of a fruit moth caterpillar utilizes fruit components as nutrient source to increase its longevity and fertility. Biological Control 44: 341-348.

IHAKa, R. \& R. Gentleman. 1996. R: a language for data analysis and graphics. Journal of Computational Statistic 5: 299314.

ImANDEH, N.G. 2006. Effect of the pupal age of Calliphora erythrocephala (Diptera: Calliphoridae) on the reproductive biology of Melittobia acasta (Walker) (Hymenoptera: Chalcidoidea: Eulophidae). Entomological Science 9: 7-11.

Jervis, M.A.; J. Ellers \& J.A. Harvey. 2008. Resource acquisition, allocation, and utilization in parasitoid reproductive strategies. Annual Review of Entomology 53: 361-85.

Moreira, M.D.; M.C.F. Santos; E.B. Beserra; J.B. Torres \& R.P. AlmeIDA. 2009. Parasistismo e superparasitismo de Trichogramma pretiosum Riley (Hymenoptera: Trichogrammatidae) em ovos de Sitotroga cerealella (Oliver) (Lepidoptera: Gelechiidae). Neotropical Entomology 38: 237-242.

Pandey, A.K. \& C.P.M. TRipathi. 2008. Effect of temperature on the development, fecundity, progeny sex ratio and life-table of Campoletis chlorideae, an endolarval parasitoid of the pod borer, Helicoverpa armigera. BioControl 53: 461-471.

Pastori, P.L.; L.B. Monteiro; M. Botton \& D. Pratissoli. 2007. Capacidade de parasitismo de Trichogramma pretiosum Riley (Hymenoptera: Trichogrammatidae) em ovos de Bonagota salubricola (Meyrick) (Lepidoptera: Tortricidae) sob diferentes temperaturas. Neotropical Entomology 36: 926-931.

Pastori, P.L.; L.B. Monteiro \& M. Botton. 2008. Biologia e exigências térmicas de Trichogramma pretiosum Riley (Hymenoptera, Trichogrammatidae) "linhagem bonagota" criado em ovos de Bonagota salubricola (Meyrick) (Lepidoptera, Tortricidae). Revista Brasileira de Entomologia 52: 472-476.

Penacchio, F. \& M.R. Strand. 2006. Evolution of developmental strategies in parasitic Hymenoptera. Annual Review of Entomology 51: 233-58. 
Pereira, F.F.; R. Barros; D. Pratissoli \& J.R.P. Parra. 2004. Biologia e exigências térmicas de Trichogramma pretiosum Riley e $T$. exiguum Pinto \& Platner (Hymenoptera: Trichogrammatidae), criados em ovos de Plutella xylostella (L.) (Lepidoptera: Plutellidae). Neotropical Entomology 33: 231-236.

Pereira, F.F.; J.P.M. Felipe; G.C. Canevari; O.H.H. Mielke; J.C. Zanuncio \& J.E. Serrão. 2008a. Biological aspects of Dirphia moderata (Lepidoptera: Saturniidae) in Eucalyptus cloeziana and Psidium guajava in Viçosa, State of Minas Gerais, Brazil. Brazilian Archives of Biology and Technology 51: 369372.

Pereira, F.F.; T.V. Zanuncio; J.C. Zanuncio; D. Pratissoli \& M.T. TAVAREs. 2008b. Species of Lepidoptera defoliators of eucalypt as new hosts for the polyphagous parasitoid Palmistichus elaeisis (Hymenoptera: Eulophidae). Brazilian Archives of Biology and Technology 51: 259-262.

Pereira, F.F.; J.C. Zanuncio; J.E. Serrão; P.L. Pastori \& F.S. Ramalho. 2009. Reproductive performance of Palmistichus elaeisis (Hymenoptera: Eulophidae) with previously refrigerated pupae of Bombyx mori (Lepidoptera: Bombycidae). Brazilian Journal of Biology 69: 865-869.

Pereira, F.F.; J.C. Zanuncio; J.E. Serrão; T.V. Zanuncio; D. Pratissoli \& P.L. PAstori. 2010. The density of females of Palmistichus elaeisis Delvare and LaSalle (Hymenoptera: Eulophidae) affects their reproductive performance on pupae of Bombyx mori L. (Lepidoptera: Bombycidae). Anais da Academia Brasileira de Ciências 82: 323-331.

Pratissoli, D.; J.C. Zanuncio; U.R. Vianna; J.S. Andrade; T.B.M. Pinon \& G.S. ANDRADE. 2005. Thermal requirements of Trichogramma pretiosum and T. acacioi (Hym.: Trichogrammatidae), parasitoids of the avocado defoliator Nipteria panacea (Lep.: Geometridae), in eggs of two alternative hosts. Brazilian Journal of Biology 48: 523-529.

Pratissoli, D.; E.F. Reis; H.B. Zago; P.L. Pastori \& T. Tamanhoni. 2006. Biologia e exigências térmicas de cinco linhagens de
Trichogramma pretiosum Riley (Hymenoptera: Trichogrammatidae) criadas em ovos de Tuta absoluta (Meyrick) (Lepidoptera: Gelechiidae). Ciência Rural 36: 1671-1677.

Sagarra, L.A.; C. Vicent \& R.K. Stewart. 2001. Body size as an indicator of parasitoid quality in male and female Anagyrus kamali (Hymenoptera: Encytidae). Bulletin of Entomological Research 91: 363-367.

UÇKAN F. \& A. GÜLEL. 2002. Age-related fecundity and sex ratio variation in Apanteles galleriae (Braconidae) and host effect on fecundity and sex ratio of its hyperparasitoid Dibrachys boarmiae (Hymenoptera, Pteromalidae). Journal of Applied Entomology 126: 534-537.

Vinson, S.B. \& G.F. Iwantsch. 1980. Host suitability for insect parasitoids. Annual Review of Entomology 25: 397-419.

WAAGE, J.K. 2001. Indirect ecological effects in biological control: the challenge and the opportunity, p. 1-12. In: E. WaJNBERG; J.K. SCOTT \& P.C. Quimby (Ed.). Evaluating indirect ecological effects of biological control. Wallingford, CABI Publishing, 288p.

Wang-Duu; Bai-Yaoyu \& Zhang-ChuanXi. 2004. A review on the nutritive value of silk worm pupae and its exploitation. Entomological Knowledge 41: 418-421.

Wilcken, C.F. \& E. Berti Filho. 2006. Biologia de Thyrinteina arnobia (Stoll) (Lepidoptera: Geometridae) em dieta artificial (I): Seleção das dietas e influência da posição da dieta artificial no desenvolvimento das lagartas. Revista de Agricultura 81: 287-300.

Zanuncio, J.C.; F.F. Pereira; G.C. Jaceues \& M.T. Tavares. 2008. Tenebrio molitor Delvare \& LaSalle (Coleoptera: Tenebrionidae), a new alternative host to rear the pupae parasitoid Palmistichus elaeisis (Hymenoptera: Eulophidae). The Coleopterists Bulletin 62: 64-66.

Zaviezo, T. \& N. Mills. 2000. Factors influencing the evolution of clutch size in a gregarious insect parasitoid. Journal of Animal Ecology 69: 1047-1057.

Submitted: 12.V.2010; Accepted: 16.VIII.2010.

Editorial responsibility: Pedro Gnaspini 